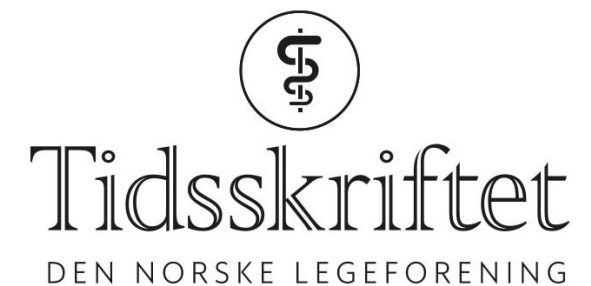

DEN NORSKE LEGEFORENING

\title{
M. Nesset \& A.G. Teien svarer
}

KOMMENTAR

MERETE NESSET

E-post: meretesmetode@gmail.com

Ingen oppgitte interessekonflikter

ANNE GRETHE TEIEN

Ingen oppgitte interessekonflikter

Vi takker for Ulrik Malts svar. Det gleder oss at Norsk psykiatrisk forening mener at «enhver pasient, innen både somatisk og psykisk helse, har rett til å reservere seg mot en bestemt type behandling». Så langt kan det synes som at vi har foreningen med oss.

I somatikken har man rett til å nekte behandling selv dersom man risikerer en tidligere død. I psykiatrien er det problematisk å hevde at noen øker sannsynligheten for å dø eller bli varig ufør ved aktivt og velbegrunnet å velge vekk nevroleptika. Psykosen er i seg selv ikke dødelig. Antipsykotika kan ha alvorlig, funksjonsnedsettende effekt, og plutselig død er en sjelden, men kjent bivirkning(1).

Vi er enige i at det finnes situasjoner der mennesker i psykose har redusert evne til å forstå og vurdere den informasjonen som gis dem om legemiddelbehandling og de valgmuligheter som finnes. Nettopp derfor mener vi at forhåndserklæringer må gjøres juridisk bindende for de som krever reservasjonsrett. En forhåndserklæring skal utformes og journalføres på et tidspunkt der pasienten uomtvistelig er samtykkekompetent. Vi forutsetter at den som reserverer seg har tilegnet seg kunnskap om og forstår rekkevidden av eget helsevalg som omhandler framtidssituasjoner der vedkommende kan risikere å bli erklært ikke samtykkekompetent. Vi vil samtidig påpeke at selv om en persons beslutningsevne skulle være vurdert kronisk nedsatt, er FNs konvensjon om funksjonshemmedes rettigheter klar på at dette ikke skal hindre retten til rettslig handleevne, innbefattet å kunne velge bort medikamenter (2). Her kommer retten til tilgang på beslutningsstøtte inn.

Malt reagerer på at vi krever at reservasjonsretten må stå så sterkt juridisk at den også hindrer medisinering på nødrett. Det er mulig det trengs lovjusteringer for å sikre pasienter en nødrettsoverskridende nektingsrett. Helsepersonell må fullt ut ta konsekvensen av bindende pasienterklæringer, og løse praktiske, ressursavhengige problemer på andre måter enn å påberope seg nødrett for å legitimere tvangsmedisinering. Plassbegrensninger og manglende kvalifisert helsepersonell er ingen unnskyldning for å underkjenne pasienters legitime, kvalifiserte valg. 
Man kan få inntrykk av at Malt undervurderer pasienter som krever reservasjonsrett mot tvangsmedisinering. Vi som står på barrikadene for denne retten, er kunnskapsrike, kompetente mennesker som krever fullt eierskap til å gjøre helsevalg på egne vegne. Vi mener tiden er overmoden for at psykiaterne med en større grad av ydmykhet oppdaterer seg på vår kunnskap om hva som faktisk hjelper oss, og ikke minst tar våre dårlige erfaringer på det dypeste alvor, med de implikasjoner det innebærer. Vi er på fornavn med antipsykotikaens påståtte effekter, og vet godt hvordan disse legemidlene virker på oss. Det er derfor vi ikke vil ha dem!

\section{LITTERATUR:}

1. Norsk legemiddelhåndbok. Antipsykotika. http://legemiddelhandboka.no/Legemidler/52082 (21.07.2017).

2. United Nations. OHCHR. Convention on the rights of persons with disabilities. General Comment No 1. 19.5.2014. http://tbinternet.ohchr.org/_layouts/treatybodyexternal/Download.aspx?sy... (21.07.2017)

Publisert: 21. august 2017. Tidsskr Nor Legeforen. DOI: 10.4045/tidsskr.17.0671 (C) Tidsskrift for Den norske legeforening 2020. Lastet ned fra tidsskriftet.no 